\section{DECOMPOSITION OF AND PRESSURE DEVELOPED BY MUSTARD GAS IN STEEL SHELL AT $60^{\circ} \mathrm{C} .{ }^{1}$ \\ By W. A. Felsing, H. Odeen and C. B. Petersen}

Chemral Laboratory, EDGEWOOd Arsenal, EDGFWOOd, Maryland Received July 14, 1920

It has been determined qualitatively that crude mustard gas (dichloroethyl sulfide) slowly attacks iron, and that it is itself slowly decomposed at room temperatures by contact with iron. Since hydrochloric acid is one of the products of this decomposition of mustard gas, and since mustard gas as commercially produced is never quite dry, the effect of the decomposition is essentially a corrosion of the iron by the hydrochloric acid with liberation of hydrogen. Since the plant of Edgewood Arsenal was loading steel shell with crude mustard gas for shipment overseas, it became highly desirable to ascertain:

(r) The extent of decomposition of the mustard gas in the steel shells cluring a two weeks' journey in cargo vessels, at temperatures as high as $50^{\circ} \mathrm{C}$.

(2) The maximum pressure that would obtain inside of the shell, in order to make provisions for a sufficiently tight or leakproof booster-shelljoint, and to provide boosters with sufficient wallthickness to prevent caving in.

Steel shell filled with mustard gas were therefore kept at $60^{\circ} \mathrm{C}$. for a period of $2 \mathrm{wks}$, in order to determine the rate of decomposition and to measure the pressures developed.

The mustard gas shipped was prepared by two processes, both based upon the interaction of sulfur monochloride and ethylene. The one (the original process, designated in this paper as Process A) employed no initial charge of mustard gas as catalyzer, was operated at $60^{\circ}$ C., and employed lead-lined reactors; the other (the Levinstein process, designated as Process B) maintained a 70 to 75 weight per cent concentration of mustard gas throughout the run until all the sulfur monochloride had been added, was operated at $30^{\circ}$ to $35^{\circ} \mathrm{C}$, and employed simple iron reactors. The products differed considerably in color, purity, amount of sulfur held in colloidal solution, acidity, etc. Both kinds of crude mustard were investigated. The vast majority of the gas, however, was prepared according to Process B.

\section{METHODS OF INVESTIGATION}

In order to gain information on the two points stated in the beginning of this paper, two series of experiments were made. The methods may be outlined as follows:

SERIES I-Three hundred cc. samples of analyzed crude Process A and Process B mustard gas were placed in several $75 \mathrm{~mm}$. shell. The shell were tightly closed by means of rubber stoppers and were kept in a thermostat at $60^{\circ} \mathrm{C} .\left( \pm_{I^{\circ}}\right)$ for a period of $\mathbf{r} 6$ days for the Process $B$ samples, and 8 days for the Process A samples. A test sample was taken every two days in the order of shell number, two successive samples being taken from each shell. Two shell contained crude Process A and four shell Process B mustard gas, both of excellent quality initially. To detect any abnormal behavior during the testing period, a final sample was taken from each of the

${ }_{1}$ Published by permission of the Chief of the Chemical Warfare Service. first four shell at the end of I 6 days for the determination of acidity and final melting point.

SERIES 2-Three hundred cc. samples of analyzed crude Process B mustard gas were placed in $75 \mathrm{~mm}$. shell connected with mercury manometers. Also, samples of Process B mustard gas which had been treated with gaseous ammonia (this procedure precipitating out about 7 to 8 per cent of the colloidal sulfur and destroying the $\mathrm{HCl}$ per cent) and of Process A mustard gas in which gas oil had been substituted for colloidal sulfur (by the process of extraction) were also placed in shell similarly arranged. As a check, samples of each material were placed in glass containers, producing the same void as in the steel shell, and connected to mercury manometers.

TABLE I-PRogressive Decomposition OF MUStard Gas IN Steel Shell

\begin{tabular}{|c|c|c|c|c|c|c|c|c|}
\hline SAMPLE & $\begin{array}{l}\dot{0} \\
2 \\
\frac{0}{0} \\
\frac{D}{\sqrt{2}}\end{array}$ & 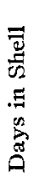 & 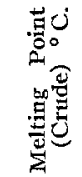 & 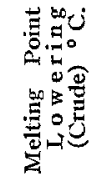 & 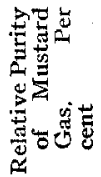 & 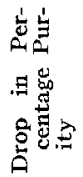 & 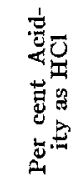 & 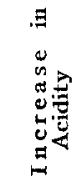 \\
\hline Process B & $\begin{array}{l}\mathrm{i} \\
1 \\
2 \\
2 \\
3 \\
3 \\
4 \\
4\end{array}$ & $\begin{array}{r}0 \\
2 \\
4 \\
6 \\
8 \\
10 \\
12 \\
14 \\
16\end{array}$ & $\begin{array}{l}8.00 \\
7.90 \\
7.50 \\
7.20 \\
7.05 \\
7.10 \\
6.95 \\
6.10 \\
6.00\end{array}$ & $\begin{array}{r}\because 0.10 \\
-0.50 \\
-0.80 \\
=0.95 \\
=0.90 \\
-1.05 \\
-1.90 \\
-2.00\end{array}$ & $\begin{array}{l}81.8 \\
81.5 \\
80.3 \\
79.4 \\
79.0 \\
79.1 \\
78.7 \\
76.1 \\
75.7\end{array}$ & $\begin{array}{l}0.3 \\
0.3 \\
1.5 \\
2.4 \\
2.8 \\
2.7 \\
5.1 \\
6.1\end{array}$ & $\begin{array}{l}0.160 \\
0.180 \\
0.382 \\
0.417 \\
0.639 \\
0.910 \\
0.645 \\
1.387 \\
1.535\end{array}$ & $\begin{array}{l}0.020 \\
0.222 \\
0.257 \\
0.479 \\
0.750 \\
0.485 \\
1.227 \\
1.375\end{array}$ \\
\hline Process A & $\begin{array}{l}\dot{5} \\
5 \\
6 \\
6\end{array}$ & $\begin{array}{l}0 \\
2 \\
4 \\
6 \\
8\end{array}$ & $\begin{array}{r}10.30 \\
9.40 \\
9.20 \\
9.60 \\
9.40\end{array}$ & $\begin{array}{r}-0.90 \\
-1.10 \\
-0.70 \\
-0.90\end{array}$ & $\begin{array}{l}88.9 \\
86.1 \\
85.5 \\
86.8 \\
86.1\end{array}$ & $\begin{array}{l}3.8 \\
3.8 \\
2.4 \\
2.8\end{array}$ & $\begin{array}{l}0.270 \\
1.028 \\
1.308 \\
0.968 \\
1.009\end{array}$ & $\begin{array}{l}0.7 \\
1.0 \\
0.6 \\
0.7\end{array}$ \\
\hline
\end{tabular}

Zero readings were taken on each manometer at $30^{\circ}$.C., the temperature of the bath when the manometers were sealed on. All connections had been tested for leaks. The temperature of the thermostat was raised to $60^{\circ} \mathrm{C}$. and maintained at this temperature $\left( \pm I^{\circ} \mathrm{C}\right.$.) for over to days. An initial pressure reading was made one hour after the thermostat had been adjusted to $60^{\circ} \mathrm{C}$. Subsequent manometer readings were made twice daily (at 8:30 A.M. and $4: 30$ P.M.).

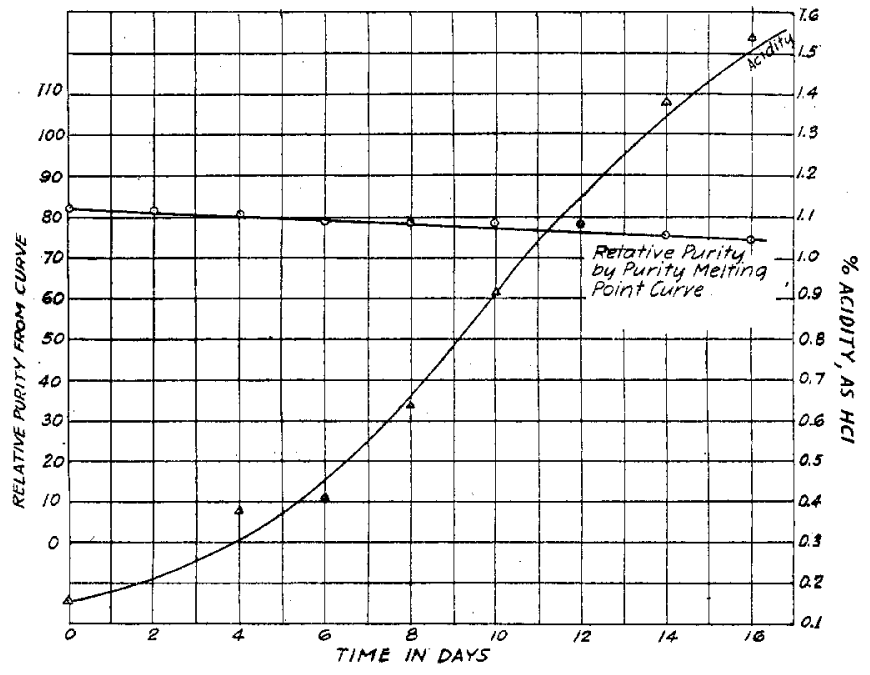

Fig. 1-Relative PURITy and Acidity as a Function of Time

$$
\text { METHODS OF ANALYSIS }
$$

The tests for the determination of the progressive decomposition consisted of vacuum distillations, melting-point determinations on the crude and the distilled 
samples, and acidity determinations. The percentage purity of the distilled product and the relative percentage purity of the crude were gaged by an empirically determined purity-melting point relation. ${ }^{1}$ Acidity determinations were made by adding chloroform (to dissolve the mustard gas) and water, and titrating with a standardized sodium hydroxide solution.

In Series 2, melting-point, acidity, and purity tests were made only at the beginning and at the end of the Io-day period.

\section{TABULATION OF RESULTS}

The results obtained in Series $I$ are presented in Tables I and II; in Fig. I are presented the meltingpoint lowerings and acidity increases as related to time in days, and in Fig. 2 the relation of melting-

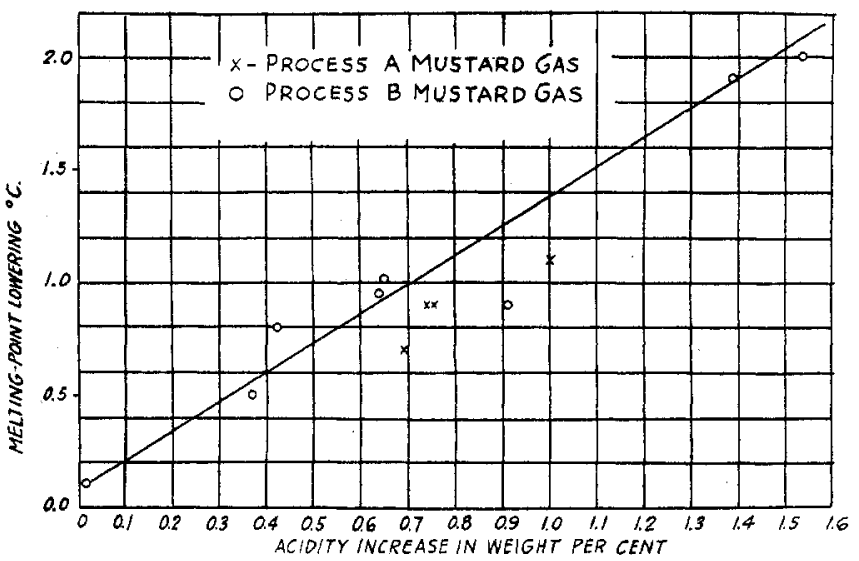

Fig. 2-MELTing-Point Lowering as a FunCtion OF ACIDIty INCREASE

point lowering to acidity increase. The results of the analysis of initial and final materials of the shell of Series 2 are presented in Table III. Net decomposition pressures were obtained by subtracting initial readings at $60^{\circ} \mathrm{C}$. from final readings at $60^{\circ} \mathrm{C}$. The thermostat temperature was lowered to $30^{\circ} \mathrm{C}$. at the end of the test period, and pressures were again read. Fig. 3 gives the total pressures corrected to initial barometer and initial zero readings on manometers. Fig. 4 gives the same relation of pressure with respect to time with the additional correction for thermal expansion from $30^{\circ} \mathrm{C}$. to $60^{\circ} \mathrm{C}$. The lowering of pressure due solely to gas absorption on cooling to $30^{\circ} \mathrm{C}$. is shown in Fig. 3 by the dotted lines at the end of each curve.

Tabre II-Melting Points and Acidity of Mustard Gas at END of

\begin{tabular}{|c|c|c|c|c|c|}
\hline \multirow[b]{2}{*}{ SAXYPIE } & \multicolumn{4}{|c|}{ 16-DAY PERIOD } & \multirow[b]{2}{*}{$\begin{array}{c}\text { Total } \\
\text { Increase } \\
\text { in Acidity }\end{array}$} \\
\hline & $\begin{array}{c}\text { Shell } \\
\text { No }\end{array}$ & $\begin{array}{l}\text { Melting } \\
\text { Point } \\
\text { ○. }\end{array}$ & $\begin{array}{l}\text { Total M.-P. } \\
\text { Lowering } \\
\text { C. }\end{array}$ & Acidity & \\
\hline Process B & $\left\{\begin{array}{l}i \\
2 \\
3 \\
4\end{array}\right.$ & $\begin{array}{l}8.0 \\
4.5 \\
5.0 \\
5.8 \\
6.0\end{array}$ & $\begin{array}{l}\dot{3} . \dot{5} \\
3.0 \\
2.2 \\
2.0\end{array}$ & $\begin{array}{l}0.160 \\
2.930 \\
1.907 \\
0.885 \\
1.535\end{array}$ & $\begin{array}{l}2.770 \\
1.747 \\
0.725 \\
1.375\end{array}$ \\
\hline Process A & $\left\{\begin{array}{l}\dot{5} \\
6\end{array}\right.$ & $\begin{array}{r}10.3 \\
7.7 \\
8.9\end{array}$ & $\begin{array}{l}2.06 \\
1.4\end{array}$ & $\begin{array}{l}0.270 \\
4.690 \\
1.862\end{array}$ & $\begin{array}{l}4.420 \\
1.592\end{array}$ \\
\hline
\end{tabular}

Table II presents the results of determinations of the melting point and the acidity on the residual mustard gas in the shell of Series $I$ at the end of 16 days.

' Bureau of Mines, Organic Report 28, April 6, 1918.
Tabte III-Analysis of OriginaI and Finaz Mustard Gas in Pressure DEVELOPMENT TESTS (AT END OF 10 DAYS)

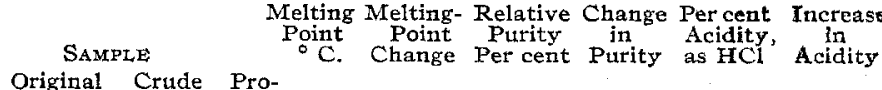
Original Crude Pro$\begin{array}{ccccccc}\text { cess B } \ldots \ldots \ldots \ldots & 8.0 & \ldots & 82.4 & \ldots & 0.175 & \ldots\end{array}$ $\begin{array}{ccccccc}\text { Process } & \text { B from steel } \\ \text { shell. } \ldots \ldots & 6.4 & -1.6 & 76.5 & -5.9 & 2.040 & 1.865\end{array}$

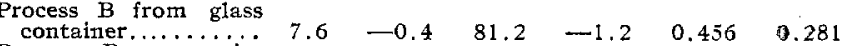
Process B, ammonia- $7.6 \quad-0.4 \quad 81.2 \quad-1.2000$ $\begin{array}{lllllll}\text { treated........... } & 8.1 & \ldots & 82.7 & \ldots & 0.005 & \ldots\end{array}$

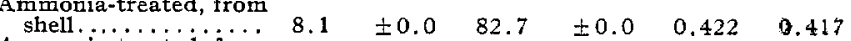

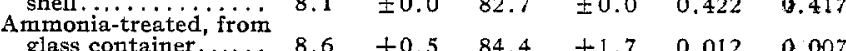

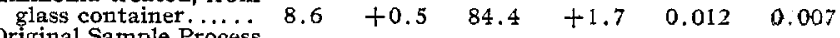
$\begin{array}{cccccc}A+12 \text { per cent oil.. } & 7.9 & \ldots & 82.1 & \ldots & 0.073\end{array}$ Process A +12 per cent

$\begin{array}{lllllll}\text { oil, from shell....... } & 7.2 & -0.7 & 80.0 & -2.1 & 0.661 & 0.588\end{array}$

\section{DISCUSSION OF RESULTS}

The data obtained in Series I offer substantial proof of a progressive decomposition of mustard gas in steel shell at temperatures near $60^{\circ} \mathrm{C}$. This time-relative purity relation for Process $B$ mustard gas is practically a linear function (see Fig. I). The increase of acidity with time in the closed steel shell is also presented in the figure, showing practically a uniform rise. An increase in acidity goes hand in hand with a lowering of melting point and a decrease in actual mustard gas content. This is shown in Fig. 2,

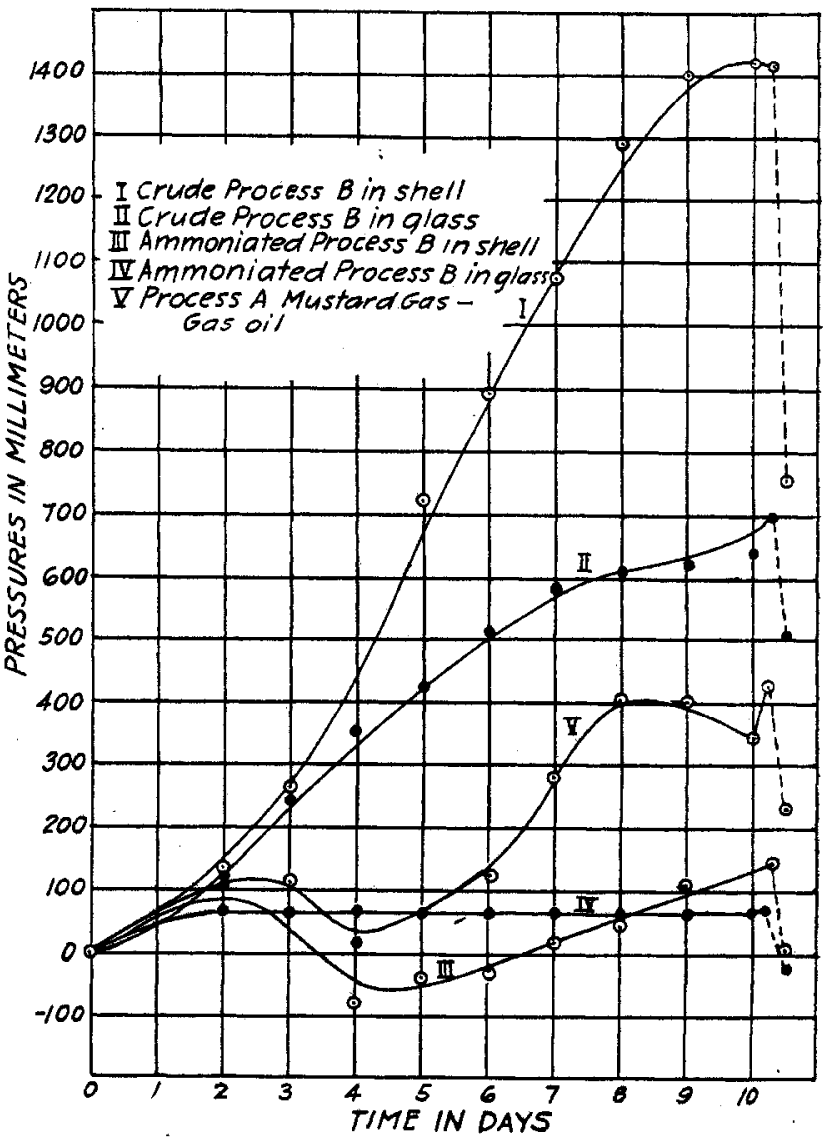

Fig. 3-Decompositron Pressure of Mustard Gas at $60^{\circ} \mathrm{C}$. (Not Corrected for Thermal Change)

The Process A mustard gas tests were continued over a period of only 8 days, and though the results are not as concordant as those on Process B mustard gas, the decomposition and the increase in acidity proceed in the same general way as for Process $B$. 


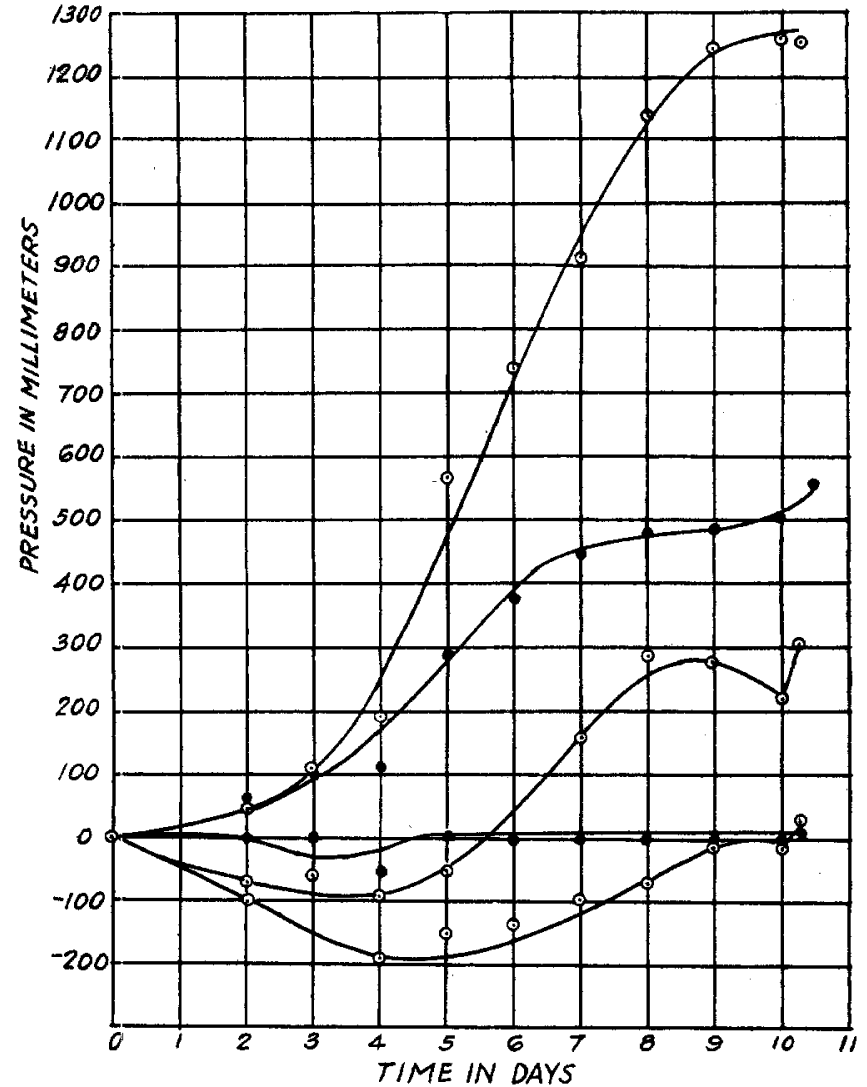

Fig. 4-Decomposition Pressure of Mustard Gas at $60^{\circ} \mathrm{C}$. (Corrected for Thermal Change)

Analysis by means of vacuum distillation does not yield satisfactory results, because the amount of sulfur precipitated out of colloidal solution varies with the time, and hence the analysis of the supernatant liquid is not a true criterion of the purity of the sample. Further, an actual decomposition of the mustard gas may be counterbalanced by a precipitation of sulfur, the precipitated sulfur adhering to the sides of the shell. The reliable criterion for determining the extent of decomposition was the melting-point determination on the undistilled mustard; since in this determination the colloidal sulfur does not affect the melting point, while the decomposition products do. Hence, a relative purity based upon these melting points is recorded, and the results given graphically in Fig. I.

In Series 2 , the relation of melting-point lowering and total acidity is again confirmed; while the relation is not the same quantitatively, the general behavior and trend is the same. The deviation may be due to several causes, but it would be idle curiosity to attempt to make an explanation.

By reference to either Figs. 3 or 4 , it will be noted that a maximum pressure development is attained in about 9 days with crude Process B mustard gas. With the ammonia-treated mustard gas a negative pressure actually obtained for 3 days, after which a slight positive pressure was built up. The negative pressure is very likely the result of the neutralization of the ammonia in solution and as a gas by the hydrochloric acid formed by hydrolysis. It is possible that if the tests had extended over a longer period, a pressure as high as with the crude mustard gas would have been obtained. The pressure developed by the ammonia-treated mustard gas in glass is practically nil, and the acidity developed is very slight.

The gas oil-mustard gas mixture in general shows a behavior similar to that of the ammonia-treated materials for the earlier part of the test. However, the pressure soon develops more rapidly and would undoubtedly reach a maximum sooner.

All samples of mustard gas in steel uniformly turned deep black, while the samples in glass remained orangeyellow. (A sample of crude Process B mustard gas, which was a light orange-yellow originally and which was sealed up in a glass tube, turned a deep black after about I6 mo. A sample of pure, colorless mustard gas, however, was still perfectly clear even after $20 \mathrm{mo}$.)

\section{CONCLUSIONS}

I-A decomposition of both Process A (original $60^{\circ} \mathrm{C}$. process) and Process B (Levinstein) mustard gas takes place in steel shell at $60^{\circ} \mathrm{C}$. The extent of the decomposition is not serious even under the severe conditions of the investigation.

2-Sulfur is deposited in solid form in shell in amounts ranging from 5 to 8 per cent of the liquid content of the shell.

3-The pressure developed in the ordinary steel shell is at most barely two atmospheres in any one shell. This seems to be a maximum or equilibrium pressure, reached after about 9 days.

4-The acid content increases considerably, but the concentration is not sufficiently high to cause serious corrosion.

5 - A preliminary treatment of the mustard gas with ammonia gas serves to delay the formation of pressure. This delay is of sufficient length to warrant the preliminary treatment of mustard gas which is to be stored for some length of time in steel shell or containers.

\section{ACKNOWLEDGMENT}

The authors desire to thank Major Wm. Lloyd Evans of the Chemical Laboratory, Edgewood Arsenal, for the timely suggestions he has given.

\section{THE PRECIPITATION OF SULFUR FROM CRUDE MUSTARD GAS BY MEANS OF AMMONIA ${ }^{1}$}

\section{By W. A. Felsing and S. B. Arenson}

Chemical Laboratory, Edgewood Arsenal, Edgewood, Maryland. Received August 19, 1920

Mustard gas ( $\beta, \beta^{\prime}$-dichloroethyl sulfide) was produced at Edgewood Arsenal by two processes based upon the interaction of liquid sulfur monochloride and ethylene gas. The following equation represents, in brief, the most probable reaction:

$$
{ }_{2} \mathrm{C}_{2} \mathrm{H}_{4}+\mathrm{S}_{2} \mathrm{Cl}_{2}=\left(\mathrm{ClC}_{2} \mathrm{H}_{4}\right)_{2} \mathrm{~S}+\mathrm{S}
$$

The equation, as written, does not indicate the formation of the intermediate compound $\mathrm{ClC}_{2} \mathrm{H}_{4} . \mathrm{S} . \mathrm{Cl}$ or of the disulfide $\mathrm{S}\left(\mathrm{C}_{2} \mathrm{H}_{4}\right)_{2} \mathrm{~S}$, both of which have been proved to be present in crude mustard gas. An inspection of the equation, however, indicates that one atomic

1 Published by permission of the Chief of the Chemical Warfare Service. 